\title{
Espectros raciais: uma história do Movimento Negro contemporâneo no Brasil
}

\author{
Racial specters: a history of the contemporary \\ Black Movement in Brasil
}

Rafael Petry Trapp

\begin{abstract}
$O$ "mundo negro": relações raciais e a constituição do Movimento Negro contemporâneo no Brasil

Amilcar Araujo Pereira

Rio de Janeiro: Pallas/Faperj, 2013. 344 p.
\end{abstract}

Nas duas últimas décadas uma grande discussão pública sobre o racismo tomou corpo no Brasil. Da aprovação da Lei 10.639, de Ensino de História e Cultura Afro-brasileira, em 2003, aos debates (e embates) em torno no Estatuto da

Rafael Petry Trapp é mestrando em História na Pontifícia Universidade Católica do Rio Grande do Sul e bolsista do CNPq (rafaelpetrytrapp@hotmail.com).

Resenha recebida em 29 de junho e aprovada para publicação em 10 de setembro de 2013.

Est. Hist., Rio de Faneiro, vol. 26, no 52, p. 519-522, julho-dezembro de 2013. 


\section{Rafael Petry Trapp}

Igualdade Racial, de 2010, passando pelos inúmeros e polêmicos programas de ação afirmativa, as questões em torno da etnicidade são parte da agenda nacional. Essa inédita conjuntura histórica não pode ser pensada sem se considerar como fundamental a atuação do Movimento Negro brasileiro, que logrou, desde o final dos anos 1970, a desconstrução do mito da democracia racial e a construção de diálogos com o Estado que possibilitaram que o antirracismo se institucionalizasse através de políticas públicas.

O livro de Amilcar Araujo Pereira, originalmente tese de doutorado defendida no Programa de Pós-Graduação em História da Universidade Federal Fluminense (UFF), traz à tona novos olhares sobre a difícil e conturbada história do Movimento Negro contemporâneo no Brasil. Trata-se, talvez, da primeira grande tentativa de síntese da história desse movimento social na história republicana brasileira. Fazendo uso de um expressivo cabedal documental, que vai de jornais da Imprensa Negra à história oral, o autor se debruça sobre a história do racismo/antirracismo no século XX.

O objetivo do livro, segundo o autor, é "examinar aspectos da história do movimento negro no Brasil e das trajetórias de algumas de suas principais lideranças" (p. 40). Identificando na questão racial o diferencial desse movimento, o autor parte, no primeiro capítulo, para uma sucinta revisão bibliográfica sobre a construção da ideia de "raça" na modernidade ocidental e alguns de seus reflexos no Brasil. A compreensão desse processo mostra como a ideia de "raça" é datada historicamente e assumiu diferentes significados ao sabor das conjunturas. Essa empresa é fundamental, pois, para além da importância da "questão racial" na história brasileira, "raça" é a categoria em torno da qual o Movimento Negro vai constituir suas perspectivas de solidariedade política e identidade étnica nos anos 1970.

O capítulo seguinte discute a conceituação de Movimento Negro e seus contextos de emergência durante o século XX. Após um breve relato sobre as primeiras organizações negras, como a Frente Negra Brasileira (FNB), da década de 1930, o autor procura estabelecer certas especificidades do Movimento Negro "contemporâneo" em relação aos que o antecederam. Ao contrário da FNB, cujo teor político recaía no assimilacionismo cultural, o movimento contemporâneo se diferenciaria por sua oposição ao mito da "democracia racial" e pela construção de uma identidade política negra. O principal marco nesse sentido é o Movimento Negro Unificado (MNU), surgido em São Paulo, em 1978. O MNU advogava uma revisão do papel do negro na história do Brasil e se opunha frontalmente aos cânones da identidade nacional da mestiçagem e da "harmonia racial".

$\mathrm{Na}$ terceira parte, Pereira busca "refletir sobre as relações entre o movimento negro contemporâneo no Brasil e as influências externas" (p. 144) no eixo Brasil-Estados Unidos-África, analisando essa relação a partir da circulação de 
referenciais no âmbito do Atlântico Negro. É, possivelmente, o ponto mais importante e original do livro. $\mathrm{O}$ olhar retorna à primeira metade do século $\mathrm{XX}, \mathrm{e}$ nesse momento é analisada uma série de matérias sobre a situação racial brasileira em dois dos mais importantes jornais da Imprensa Negra estadunidense, o The Baltimore Afro-American, de 1896, e o Chicago Defender, de 1905.

$\mathrm{O}$ autor mostra, com propriedade, o intenso trânsito de ideias que se constituiu entre ativistas da questão negra dos Estados Unidos e do Brasil, já nos anos 1920, através, por exemplo, das trocas de informações e referenciais entre os jornais O Clarim d'Alvorada e Chicago Defender. Além de indicar como a imagem "racial" do Brasil constituía elemento contrastante importante para os negros norte-americanos, percebemos aí as modificações dessa mesma imagem ao longo das décadas nesses jornais nos Estados Unidos. Pereira demonstra que o próprio Movimento Negro norte-americano tinha como elementos importantes a pluralidade e a diversidade de concepções de afirmação cultural e luta política, constituindo-se também a partir de influências externas.

Essa discussão responde, primordialmente, ao já extenso debate sobre a "americanização" do Movimento Negro brasileiro, que se insere, por sua vez, na tradição comparativa de estudos sobre as "relações raciais" no Brasil e nos Estados Unidos. Investindo sobre a assertiva de que o Movimento Negro brasileiro dos anos 1970 não seria mais do que uma "cópia" do norte-americano, e de que teria importado "ideias fora do lugar", Pereira conclui que "o movimento negro nunca foi apenas receptor", mas serviu até mesmo como "referencial para outros negros em suas lutas na diáspora" (p. 164). Esse aspecto do Movimento Negro brasileiro enfatiza uma escolha teórica bastante acertada da obra em questão, qual seja, a de pensar as lutas negras sob o signo da transnacionalidade, para além das demarcações materiais, simbólicas e epistêmicas das fronteiras nacionais.

Embora indique por alto com quem está dialogando, o autor traz elementos empíricos novos e dá mais nós no novelo da discussão da "questão racial", construindo um espaço na historiografia sobre racismo/antirracismo no Brasil. Sob muitos aspectos, o livro é um avanço em relação a outras tentativas de interpretação do Movimento Negro brasileiro, como, por exemplo, a empreendida por Michael Hanchard em seu marcante Orfeu e o poder, de 1994. Em que pese a profundidade da tese de Hanchard, ao contrário deste, Pereira desloca o olhar para o Brasil como um todo e vai além dos apriorismos analíticos de Orfeu e o poder.

Ao demonstrar a complexidade da formação do Movimento Negro contemporâneo, as redes de relações entre os militantes entre si e com o Estado, as múltiplas influências e a criação e usos de uma memória de luta antirracista, o autor consegue, pelo desnudamento da historicidade do Movimento Negro, se resguardar de um espectro analítico subsumido a projetos políticos e engaja- 


\section{Rafael Petry Trapp}

mentos mais passionais. Esse tipo de abordagem constitui, malgrado sua importância política, grande parte dos trabalhos sobre a questão negra e do racismo/antirracismo no Brasil.

A despeito dos acertos, alguns pontos importantes poderiam ter sido mais bem trabalhados. A interlocução teórica com o conceito de Atlântico Negro, tal como concebido por Paul Gilroy, carece de aprofundamento. Aceita-se a existência desse espaço teórico-metafórico como algo dado, como se as especificidades da experiência negra e antirracista no Brasil não concorressem para tensionar a própria ideia de Atlântico Negro, posto que no livro de Gilroy a história escravista e negra brasileira é praticamente ignorada.

Por outro lado, uma análise de história intelectual da questão racial poderia ter sido incluída para enriquecer o debate. Autores fundamentais como Gilberto Freyre, Florestan Fernandes, Clóvis Moura, Abdias do Nascimento, entre outros, são parcamente analisados em sua relação com a construção do Movimento Negro contemporâneo. Além disso, um olhar mais atento ao tempo presente ensejaria ao autor inserir-se de maneira mais enfática em debates candentes da contemporaneidade, como a questão da "racialização", capitaneada pelo Movimento Negro, e seus impactos nas políticas públicas antirracistas. 